\title{
DIFFERENTIATION OF DELTA SEDIMENTS OF SIELPIA WATER RESERVOIR (ŚWIĘTOKRZYSKIE VOIVODESHIP, POLAND) PRELIMINARY RESULTS
}

DOI: https://doi.org/10.18509/AGB.2021.02

UDC: $551.435 .12(438)$

\author{
Tomasz Kalicki ${ }^{1}$, Paweł Przepióraa ${ }^{1}$, Piotr Kusztal ${ }^{2}$, Michał Aksamit ${ }^{2}$, \\ Paulina Grzeszczyk², Marcin Frączek¹, Michał Jabłoński², Mateusz Wrochna2
}

\author{
${ }^{I}$ Institute of Geography and Environmental Sciences, Jan Kochanowski University in Kielce, Poland \\ ${ }^{2}$ Student Science Club of Geomorphologists „,Złoty Bażant”, Jan Kochanowski University in Kielce, Poland
}

corresponding author: m.aksamit1989@gmail.com

submitted: 05.04.2020

accepted: 10.06 .2020

published: 30.09 .2020

\begin{abstract}
The Sielpia Reservoir is located on Czarna Konecka river in the northern part of Świętokrzyskie Voivodeship (central Poland), about $30 \mathrm{~km} \mathrm{NW}$ from Kielce. This area is part of the Old Polish Industrial District, which was developed from the Middle Ages. The river was used to power up many ironworks, forges and water mills. This lead to appear many industrial ponds in the river. The Sielpia Reservoir is located in one of this kind of industrial ponds place. It was built in 1821 and use as industrial pond to 1921 and next it was drainage as result of dam failure in 1930s. The modern reservoir was built in the 1960s and currently has a retention and tourist function. The hydrotechnical works began in 2018 during which the reservoir was drained in order to deepen it. During this work, numerous subfossil trunks found in the alluvial bed of the reservoir underlying limnic deposits were dated using the radiocarbon and dendrochronological methods to La Tène-Middle Age period. Stratigraphic position, as well age of the oaks that were fallen during the phases of increased fluvial activity even before the development of the metallurgical industry and deforestation, they indicate that both historical and modern reservoir in Sielpia were very shallow, and its sediments were underlain with the Subatlantic alluvial floodplain. In the Czarna Konecka estuary into the reservoir a delta was formed. A geological cross-section was made here, and samples were taken from the profiles for grain size analysis. The sediments are bipartite here. The lower lake link is made of sands with organic matter, while the upper, sandy, builds a delta. This form was created, among others due to many flash floods caused by failures of the dams of former industrial ponds located upstream of the Sielpia Reservoir.
\end{abstract}

\section{INTRODUCTION}

The Sielpia Reservoir is located in the northern part of the Świętokrzyskie voivodeship (central Poland), about $30 \mathrm{~km}$ to the NW from Kielce (Fig. 1). It is located in the Czarna Konecka catchment, which drains the north-west Mesozoic margin of the Holy Cross Mountains. This area was part of the Old Polish Industrial District, where the metallurgy has developed since the Middle Ages, while the first traces of iron ore mining and smelting date back to the Roman periods [1], [2]. With the spread of the water wheel, the energy of the rivers began to be used to power many forges and water mills. This led to construction of many industrial ponds on the rivers and creating the anthropogenic small-scale water retention system (ASWRS) [3]. The Sielpia Reservoir was established in 1821 as an industrial pond and was used until 1921, when the local metallurgical facilities are no longer profitable and were closed [4]. In the 1930s, the dyke was broken due to neglect of hydrotechnical infrastructure and floods. Silting of the reservoir has reduced its retention properties. To excessive silting led to, i.a. disappearance of 19 th $\mathrm{c}$. industrial ponds located between Sielpia and Piekło [5], [6], [7] in 19151938 [8]. Abandoned and neglected dams have many failures leading to catastrophic flows not recorded here in natural conditions. Deep erosion led to transport and accumulation of material at the estuary of Czarna Konecka river to the Sielpia Reservoir. In the 1960s, the new reservoir with retention and recreation functions was built. As a result of breaking the dams in Małachów (1970s, 1982 and 1993) and Janów $(1976,1994)$ that led to catastrophic flows, the reservoir was silted again [9], [10], [11], [12], [13]. The effect of transporting large amounts of material to the reservoir was the 
formation of an inland delta (Fig. 2). The Sielpia Reservoir reduced its area by $16 \%$, from 60 ha in 1974 to 55 ha in 2015 [13]. In 2018, due to the significant shallowing of the reservoir, its revitalization began, consisting in its drainage and deepening. During the hydrotechnical works, many subfossil trunks were found (Fig. 3), which lay at a depth of 2 to 4 meters below the bottom of the modern reservoir, in the the Czarna Konecka river estuary area.

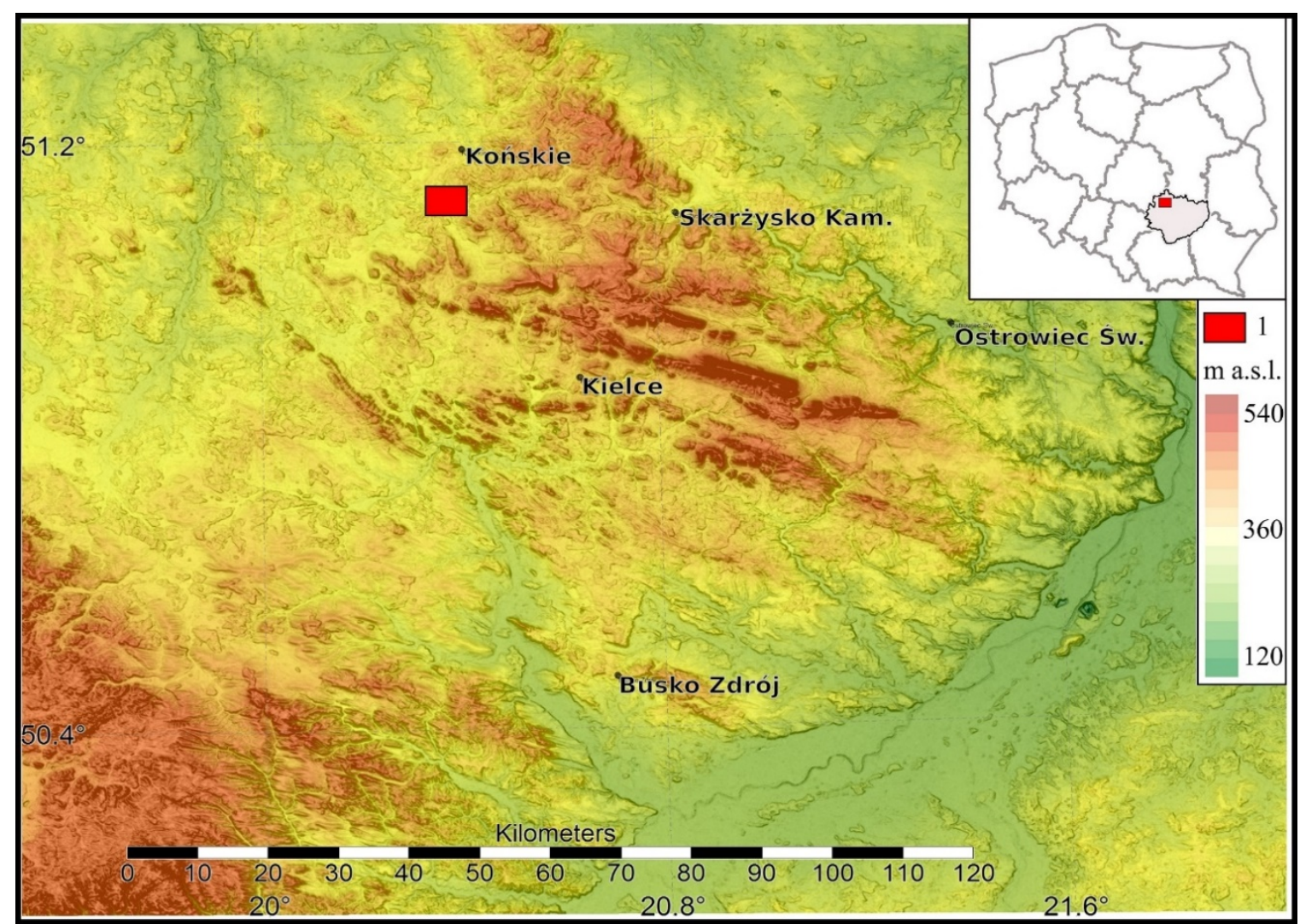

Figure 1. Location of the study area (1); DEM ed. by M. Frączek based on data from CODGiK (MGGP Aero, Nr GI-FOTO.703.44.2014) .

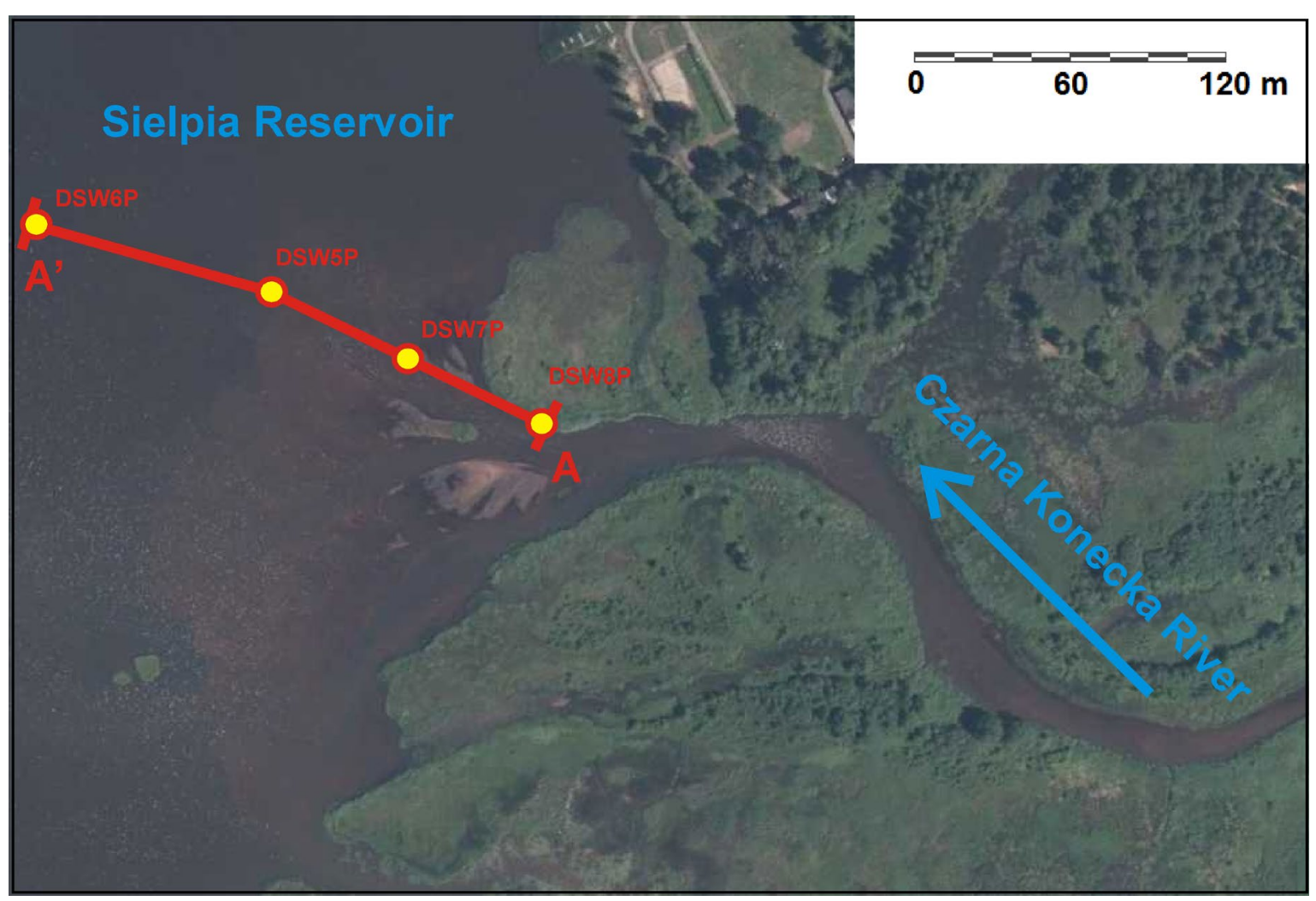

Figure 2. The orthophotomap of delta with profiles and cross section location [14]. 


\section{AIM OF THE STUDY AND METHODS}

The aim of the study was to identify sediments filling the SE part of the Sielpia Reservoir and to determine the processes that contributed to the inland delta forming. The hydrotechnical works began in 2018 and were continued from January to May 2019, during the reservoir was drained. This gave the opportunity to field studies carry on. An opencast profiles and boreholes were made within the delta area and sam ples were taken for grain size analysis made by sieve and laser methods. The results were presented in graphic form using the "GRANULOM" program [15], [16], as well as a schematic section across the delta was made. The subfossil trunks were exposed during

\section{RESULTS}

Near of the Czarna Konecka river estuary into the Sielpia Reservoir (DSW8P profile), mainly varigrained sands dominate (medium and coarse sands). In the next profiles (DSW7P, DSW5P and DSW6P) the delta sediments are admixed with gravels. A dark layer of sediments with organic matter is visible in the profiles bottom. This material is usually built of medium sands, hydrotechnical works (Fig. 3). Samples were taken from them and dated by radiocarbon and dendrochronological methods (Laboratorium Datowań Bezwzględnych at Skała).and boys, in the two different working conditions, taken separately (outdoors, noted in the lower right indicates " 0 " and halochamber, noted down right indicates "h"). Each biometric characteristic, taken in the study, was represented in the same coordinate system, having in order $\mathrm{C}(\%)$ and in the abscissa time in months. Based on these graphs, the evolution of each group of students was appreciated and the influence of saline aerosols and reformulated solions in situ on the characteristics studied was established.

sometimes with an admixture of finer, silty deposits and also single gravels occur. This black layer is finer than the sediments located in the profiles top (Fig. 4). A longitudinal cross section of the delta with a length of about $200 \mathrm{~m}$ was made. The delta sediments accumulate on lacustrine deposits (black one) in three distinct phases (Fig. 5).

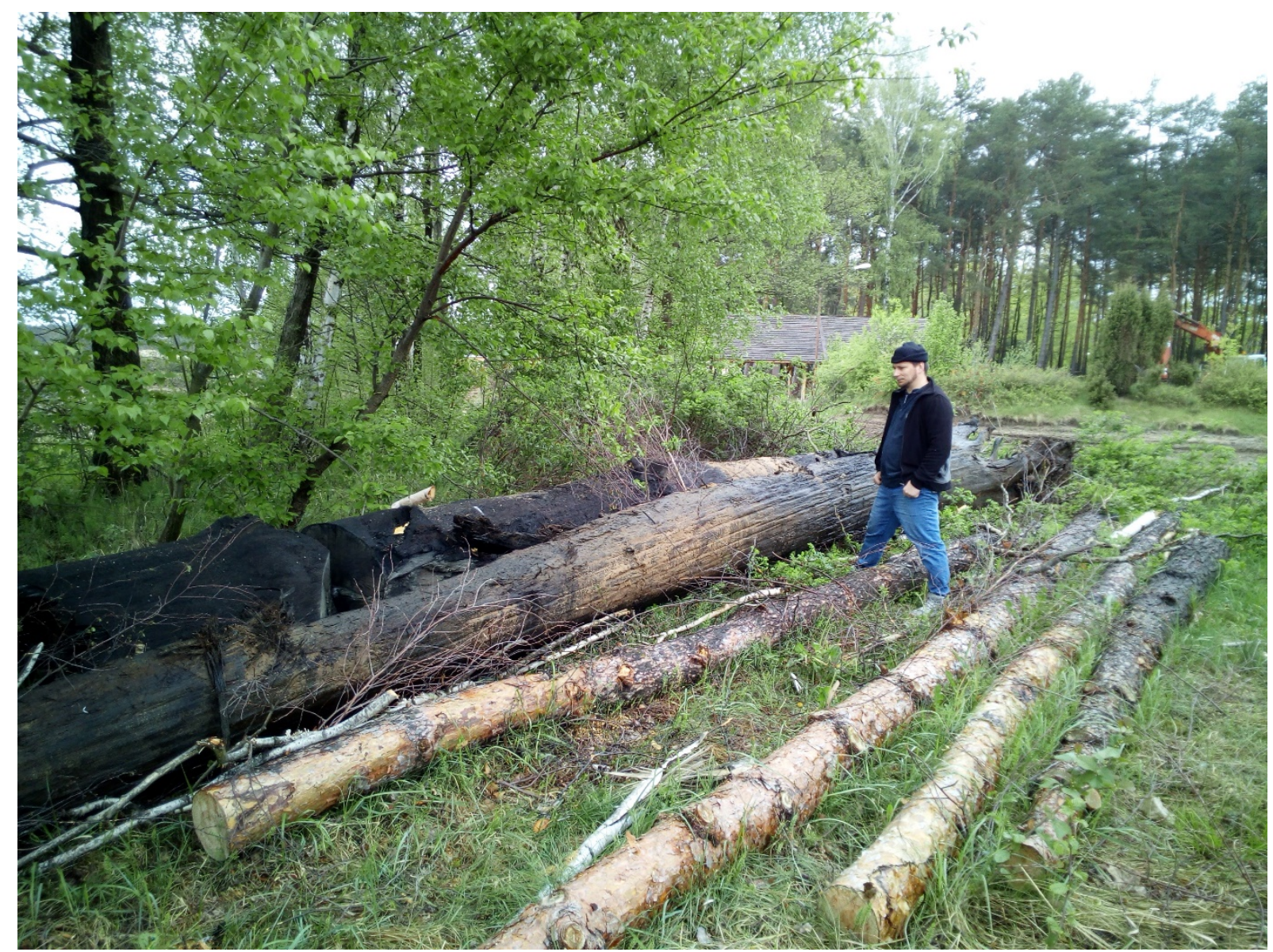

Figure 3. Two subfossil oaks (on left) drawn from sediments 


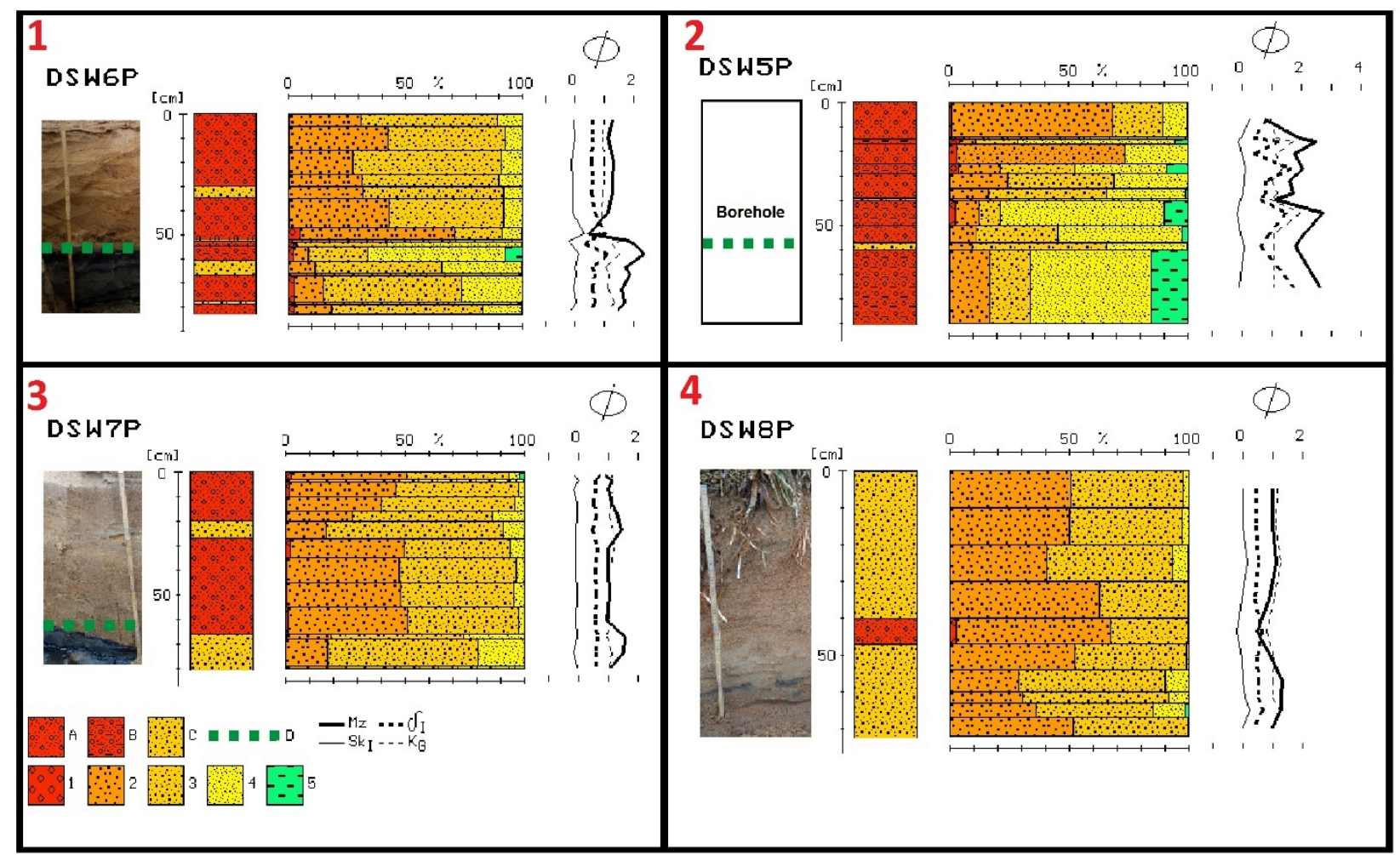

Figure 4. The results of granulometric analysis of deposits from selected delta profiles.

Lithology: A - sands with single gravels, B - silty sands with gravels, C - medium sands, D - top of lacustrine sediments; Fractions: 1 - gravel (below $-1 \varphi)$; 2 - coarse sand $(-1-1 \varphi), 3$ - medium sand $(1-2 \varphi), 4$ - fine sand $(2-$ $4 \varphi$ ), 5 - silt and clay (above $4 \varphi$ ); Folk-Ward's grain size distribution parameters: $\mathrm{Mz}-$ mean size, $\delta \mathrm{I}-$ standard deviation, SkI - skewness, KG - kurtosis;

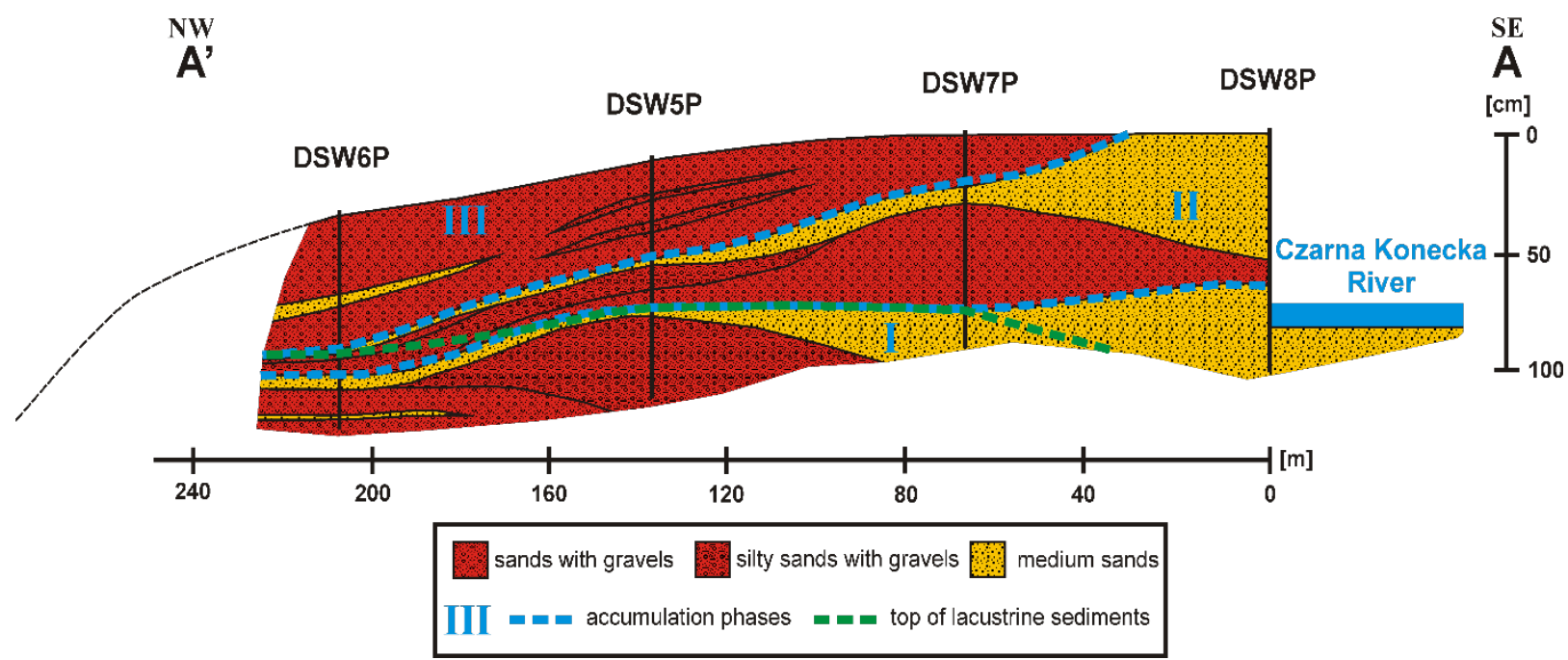

Figure 5. Figure 5. Schematic longitudinal section across delta(accumulation phases based on lithology, top of lacustrine sediments based on field observations).

A numerous subfossil trunks were taken from the sediments. Several of them were deposited below the modern reservoir lacustrine deposits. The dates obtained from them using the radiocarbon and dendrochronological method are from the La Tène period to the Middle Ages (Table 1) where the following results were obtained: $2310 \pm 35 \mathrm{BP}$ cal.
429-211 BC (MKL-4573), 1530 \pm 35 BP cal. 427601 AD (MKL-4575), 1100 \pm 40 BP cal. 778-1022 AD (MKL-4576), 1090 \pm 35 BP cal. 888-1018 AD (MKL-4577), 930 \pm 35 BP cal. 1023-1184 AD (MKL-4574). The following results were obtained from dendrochronological dating: 651-733 (fallen after $740 \mathrm{AD}$ ) and 995-1215 (fallen after $1225 \mathrm{AD}$ ). 
Table 1. Results of radiocarbon and dendrochronological dating of subfossil trunks located below reservoir sediments.

\begin{tabular}{|c|c|c|}
\hline No. & Date & Description \\
\hline 1 & $\begin{array}{l}2310 \pm 35 \text { BP cal. } 429-211 \text { BC } \\
(M K L-4573){ }^{14} \mathrm{C}\end{array}$ & $\begin{array}{l}\text { La Tène-Roman phase 2,35-1,8 (7) ka BP } \\
{[17],[18]}\end{array}$ \\
\hline 2 & $\begin{array}{l}1530 \pm 35 \text { BP cal. } 427-601 \text { AD } \\
(M K L-4575){ }^{14} \mathrm{C}\end{array}$ & Middle Age phase $5^{\text {th }}-6^{\text {th }}\left(7^{\text {th }}\right)$ c. AD [17], [18] \\
\hline 3 & 651-733 (fallen after 740 AD) Dendro. & $\begin{array}{l}\text { Period without regional phases of increase of fluvial } \\
\text { activity }\left(8^{\text {th }}\right)[17],[18]\end{array}$ \\
\hline 4 & $\begin{array}{l}1100 \pm 40 \text { BP cal. } 778-1022 \text { AD (MKL- } \\
4576){ }^{14} \mathrm{C}\end{array}$ & Middle Age phase $10-11^{\text {th }}$ c. AD [17], [18] \\
\hline 5 & $\begin{array}{l}1090 \pm 35 \text { BP cal. 888-1018 AD (MKL- } \\
4577){ }^{14} \mathrm{C}\end{array}$ & $\begin{array}{l}\text { Middle Age phase } 10-11^{\text {th }} \text { c. AD [17], [18] (Abies } \\
\text { alba) }\end{array}$ \\
\hline 6 & $\begin{array}{l}\text { 930 } \pm 35 \text { BP cal. 1023-1184 AD (MKL- } \\
4574){ }^{14} \mathrm{C}\end{array}$ & Middle Age phase $10-11^{\text {th }}$ c. AD [17], [18] \\
\hline 7 & 995-1215 (fallen after 1225 AD) Dendro. & Middle Age phase $13-14^{\text {th }}$ c. AD [17], [18] \\
\hline
\end{tabular}

\section{DISCUSSION}

Since the modern Sielpia Reservoir construction, upstream of study area in the Czarna Konecka river valley near Janów and Małachów, a few failures of neglected and abandoned dams took place.

This led to sudden drainage of reservoirs and catastrophic flows not recorded here in natural conditions [3]. This led to increase of headward erosion on the river downstream of Janów and accumulation at the Czarna Konecka estuary to the Sielpia Reservoir.

The high riverbanks under the Pleistocene terraces upstream of the reservoir was cut. Also the deepening of the riverbed at the former industrial ponds site led to an increase in the amount of material transported and accumulated in the Sielpia Reservoir [19].

The coarse sand that builds the delta was transported from the sediments filling bottom of the ponds, located upstream of the Sielpia Reservoir. This material was deposited during flash floods caused by breaking dams.

The many, single slags found in the delta sediments are marker of those catastrophic events [3], [10], [11]. The effect of these erosion processes upstream of study area was accumulation and formation of a distinct inland delta in the Sielpia Reservoir. The obtained results indicate that the delta was built in

\section{CONCLUSIONS}

In the SE part of the Sielpia Reservoir, in the last decades a delta was formed as the result of flash floods associated with rupturing of dams of smaller, former ponds located upstream of the study area. This increased erosion processes and the amount of material accumulated in the reservoir at Sielpia. The delta is built mainly by medium and coarse sands with single gravels and fragments of slag. The slag appearance confirms the origin of the sediments accumulated here as the former industrial ponds deposits. The delta was formed in three three phases, which were characterized by strong flows (flash floods), marked by coarse sediment strata. The finer material (without gravels) indicates a reduction of flow dynamic, at least at the end of phase I and II. The sediments from phase III could have been partly changed by man, among others during hydrotechnical works. The lacustrine sediments are characterized mainly by dark colour left by decomposed organics. These deposits are poorly readable in grain size (slightly finer material than delta deposits).

The reason may be that earlier the bottom of the reservoir formed older (La Tène-Middle Age) alluvial sands of Czarna Konecka river with subfossil trunks. The stratigraphic position and age of the trunks (Fig. 3, Table 1) indicates their fall in the phases of an increased fluvial activity [18], [20], even before the metallurgical industry developed here.

The oldest date indicates the period of Roman influence (429-211 BC), while the others date from the early to the late Middle Ages period (1225 AD) (Table 1). In terms of species, black oaks dominated here with few silver fir trunks (Abies alba). It also indicates that both the old and modern reservoir in Sielpia was very shallow, and its deposits covered the channel alluvia of the Subatlantic floodplain.

phases and covered the black, sandy lacustrine sediments with organic matter.The subfossil trunks located in analyzed part of the reservoir were found at a depth of about 2 to $4 \mathrm{~m}$, i.e. below of the modern reservoir sediments.

Together with the obtained dates, it confirms that these trees were fallen even before the development of historical metallurgy. This also indicates that the former and current reservoir was very shallow (the depth of the current reservoir ranged from 30 to 160 $\mathrm{cm}$ in 2018). The Sielpia Reservoir is located on the 
area of the Subatlantic flood plain of Czarna Konecka river, where trees were fallen by natural processes (bank erosion), even before the valley was transformed by human impact.

\section{ACKNOWLEDGMENTS}

Many thanks to manager of Sielpia Lake, mayor of the city and commune Końskie, Krzysztof Obratański for permission to carry out the survey in the reservoir area.

\section{REFERENCES}

[1] Bielenin K. Starożytne górnictwo i hutnictwo żelaza w Górach Świętokrzyskich, Wydanie drugie, poszerzone i poprawione, Kieleckie Towarzystwo Naukowe, 1993.

[2] Orzechowski Sz. Zaplecze osadnicze i podstawy surowcowe starożytnego hutnictwa świętokrzyskiego, Kieleckie Towarzystwo Naukowe, Kielce, 2007.

[3] Kalicki T., Frączek M., Przepióra P., Kusztal P., Kłusakiewicz E. \& Malęga E. Late Quaternary geomorphology and geoarchaeology in the rivers of the Holy Cross Mountains region, Central Europe. Quaternary Research, Vol. 91, (2), pp 584-599, 2019.

[4] Szot-Radziszewska E. Postindustrialne dziedzictwo Staropolskiego Okręgu Przemysłowego w krajobrazie kulturowym Kielecczyzny: zagrożenia i szanse, Ochrona Zabytków, vol. 62, no. 4, pp 69-82, 2009.

[5] Karte West Galizien 1801 - 1804, [in:] First Military Survey

[6] Topographic Map of the Polish Kingdom in scale 1:126 000 (Końskie sheet, Kol. III. Sek. VI), Kwatermistrzostwo Generalne Wojska Polskiego, rosyjski Korpus Topografów, Petersburg, 1843.

[7] West Osteuropa in scale 1: 25000 (XXVII-7-F Gruppe Warschau), Kart. Abt. des stellv. Generalstabes der Armee, 1915.

[8] Tactical Map of Poland in scale 1:100 000 (Końskie sheet, Pas 44, Słup 31), Wojskowy Instytut Geograficzny, Warsaw, 1938.

[9] Grzyb H., Zięba B., Piotrowicz A. \& Pachołowiecka-Grzyb H. Ekspertyza wraz z koncepcją zabezpieczenia dna rzeki Czarnej Malenieckiej przed erozją i zamulaniem zbiornika w Sielpi (część opisowo-zestawieniowa), Na zlec. WZMiUW w Kielcach, Kielce, pp 1-33, 1995.

[10] Kalicki T., Przepióra P. \& Kusztal P. Anthropogenic flash floods on two selected rivers of Holy Cross Mts. region in $20^{\text {th }}$ c. - origin and effects, Prace i Studia Geograficzne UW, vol. 64, no. 1, pp 21-36, 2019.

[11] Kalicki T., Przepióra P. \& Kusztal P. Origin and effects of anthropogenic flash floods on rivers of Holy Cross Mts. region (Poland) in $20^{\text {th }}$ c., Acta Geobalcanica, vol. 5, no. 2, pp 85-92, 2019.

[12] Kalicki T., Przepióra P., Kusztal P. \& Nowak M. Anthropogenic flash floods on rivers of Holy Cross Mts. region in $20^{\text {th }}$ c. - origin and effects, 3rd Disaster Risk Reduction Conference, Warsaw, pp 49, 2017.

[13] Kowalik M., Przepióra K., Jędrzejczyk M., Milner B., Basiński K. \& Wachecki M. Koncepcja programowoprzestrzenna odbudowy zbiornika wodnego Sielpia, Instytut OZE, Kielce, pp 1-131, 2015.

[14] geoportal.gov.pl.

[15] Folk R.L. \& Ward W.C. Brazos River bar: A study in the significance of grain size parameters, Journal of Sedimentary Research, vol. 27, no. 1, pp 3-26, 1957.

[16] Racinowski R., Szczypek T. \& Wach J. Prezentacja i interpretacja wyników badań uziarnienia osadów czwartorzędowych, Wydawnictwo Uniwersytetu Śląskiego, Katowice, Poland, pp 1-146, 2001.

[17] Starkel L. Historia doliny Wisły (od ostatniego zlodowacenia do dziś). Monografie Geograficzne IGiPZ PAN, 2, pp 1-267, 2001.

[18] Kalicki T. Zapis zmian klimatu oraz działalności człowieka i ich rola w holoceńskiej ewolucji dolin środkowoeuropejskich. Prace Geograficzne, 204. Polska Akademia Nauk, Instytut Geografii i Przestrzennego Zagospodarowania, Warsaw, 2006.

[19] Aksamit M., Kusztal P., Kalicki T., Grzeszczyk P. \& Przepióra P. Silting of the Sielpia water reservoir in the 20th and 21st c. (Central Poland), Proceedings of 5th International Scientific Conference GEOBALCANICA, Republic of North Macedonia, pp 101-105, 2019.

[20] Starkel L., Kalicki T., Krąpiec M., Soja R., Gębica P., Czyżowska E., Hydrological changes of valley floor in the upper Vistula basin during late Vistulian and Holocene, [in:] L. Starkel, T. Kalicki (ed.), Evolution of the Vistula river valley during the last 15.000 years. Part 6, Geographical Studies. Special Issue, 9, Wydaw. Continuo, Wrocław, 1996. 